\title{
Recent Extremes of Drought and Flooding in Amazonia: Vulnerabilities and Human Adaptation
}

\author{
Jose A. Marengo, Laura S. Borma, Daniel A. Rodriguez, Patrícia Pinho, \\ Wagner R. Soares, Lincoln M. Alves \\ Earth System Science Center CCST/National Institute for Space Research INPE, Sao Paulo, Brazil \\ Email: jose.marengo@inpe.br
}

Received December 8, 2012; revised January 10, 2013; accepted January 19, 2013

Copyright (C) 2013 Jose A. Marengo et al. This is an open access article distributed under the Creative Commons Attribution License, which permits unrestricted use, distribution, and reproduction in any medium, provided the original work is properly cited.

\begin{abstract}
The present study focuses on the impacts of extreme drought and flooding situations in Amazonia, using level/discharge data from some rivers in the Amazon region as indicators of impacts. The last 10 years have featured various "once in a century" droughts and floods in the Amazon basin, which have affected human and natural systems in the region. We assess a history of such hazards based on river data, and discuss some of the observed impacts in terms of vulnerability of human and natural systems, as well as some of adaptation strategies implemented by regional and local governments to cope with them. A critical perspective of mitigation of drought and flood policies in Amazonia suggests that they have been mostly ineffective in reducing vulnerability for the majority of the population, constituting, perhaps, examples of maladaptation via the undermining of resilience.
\end{abstract}

Keywords: Climate Variability; River Level; Vulnerability; Amazonia; Extremes; Hazards

\section{Introduction}

The last seven years have featured severe droughts and floods in Amazonia, with some of these events being characterized at the time as "once-in-a-century" seasonal extremes. Most of these events were classified as such using river data statistics. Flood and drought hazards represent the integrated impacts due to changes in rainfallacross the basin. The record flooding in the Amazon in 2012 surpassed the previous record extreme of 2009, and river levels during the droughts of 2005 and 2010 were among the lowest during the last 40 years [1-4].

Droughts and floods, part of the natural climate variability inthose regions, have occurred in the past and will continue to occur in the future. The inhabitants of the region are well adapted to this hydrological interannual dynamics and, over time, have been able to develop their livelihood strategies in an "optimum manner" [5]. Hydrological extremes affect not only human activities and economy but also ecosystems, with large potential impacts on regional biogeochemical and carbon cycles, particularly during droughts due to forest fires and biomass burning [6-8].

Various studies have shown that interannual variability of rainfall and river levels in the Amazon region can be, in part, attributed to the sea surface temperature (SST) variations in the tropical Pacific, manifested as the extremes of El Niño-Southern Oscillation (ENSO), and to the meridional SST gradient in the tropical Atlantic, or to a combination of both (See reviews in [9-11] and references quoted therein). So far, observations do not show any unidirectional trend in rivers or rainfall, noticingexhibiting, instead, decadal variations linked to natural climate variability $[12,13]$.

Droughts and floods represent the main impacts of extreme hydrometeorological situations, affecting population living on the riverbanks both in rural and urban areas, as well as small scale and commercial transportation, small farmers and fisheries [14]. During the droughts of 2005 and 2010, navigation along sections of the Madeira and upper and central Amazon River had to be suspended because the water levels fell to extremely low levels, which led various countries of the Amazon region to declare a state of emergency in September 2005 [1]. In contrast, during the floods of 2009 [3] and 2012, the rising levels of the Solimões and the Negro rivers, the two main branches of the Amazon River, caused floods in urban and rural areas along the riverbanks in Peruvian, Colombian and Bolivian Amazonia.

The present study focuses on 1) analyses of observed impacts of extreme drought and flooding situations in 
Amazonia on natural and human systems, using river level/discharge data as indicators of such impacts; 2) the use ofriver level/discharge data as a tool of adaptation by the local population; and 3) a discussion ofcurrent adaptation strategies implemented by regional and local governments to cope with some observed recent extremes. Section 2 introduces a history of droughts and floods in Amazonia. Section 3 describes some aspects of vulnerability of local populations to recent droughts and floods, and Section 4 shows some examples of adaptation practices adopted by the government during those recent extremes. Section 5 presentssome discussions ofdifferent adaptation strategies that would decrease vulnerability in times of droughts and floods.

\section{A Review on Rainfall-River Variability in the Amazon Region: History of Droughts and Floods in Amazonia}

Drought events in Amazonia have been reported as early as in 1911-1912 and 1925-1926 [15,16], and episodes considered as extreme ones were documented in these years and in 1964, 1983, 1997, 2005 and 2010, with great impacts on the population and ecosystems [17-20]. In addition, severe flooding episodes have been documented in 1954, 1989, 1999, 2009, 2011 and 2012, linked in some cases to La Niña or to a warm tropical South Atlantic $[3,4,21]$.

Most of the extreme episodes cited above have been detected using the river records at the Manaus gauge site on the Rio Negro, provided by the Brazilian Water Agency (Agência Nacional de Águas-ANA). This gauge station has operated since 1902, providing continuous and high quality data. For example, the droughts of 2005 and 2010 and the floods in 2009 and 2012 were detected as the lowest daily minimum and the largest daily maximum, respectively, of the levels of the Rio Negro at Manaus.

Additionally, it is observed, from level/discharge data, that some river minima/maxima are not caused only by deficit/excess of rainfall but they and their occurrence and duration are conditioned by the hydrodynamics of the basin and the relative timing of responses of northern and southwestern tributaries [22].

In "normal" years, the levels at Manaus are highest during May-July, and reflect the effects of the Rio Negro (Northern Amazonia) and the Solimões River waters (Southern Amazonia). Rainfall over the Rio Negro basin peaks in March-May and over the Solimoes basin it peaks earlier, in December-February. However, it was observed that, during extreme years, this seasonality is changed [22].

In this paper, to characterize the long-term level/discharge variability of the Amazon basin hydrology, sta- tion observations of the Rio Negroat Manaus and the Amazon River at Óbidos were used from the beginning of their records (1903-2012 for Manaus, and 1970-2012 at Óbidos) (Table 1). Additional information includes data from the Madeira River basin (1968-2012 at Fazenda Vista Alegre). The Rio Negro is the main northern tributary to the main stream, while Madeira River is the main southern tributary. Further details about the hydrological stations can be found in [22].

Figures 1 and 2 show the mean minimum/maximum annual levels of the Rio Negro at Manaus, the Madeira River at Fazenda Vista Alegre and the Amazon River at Óbidos, expressed as anomalies from the long term mean.

The minimum levels (Figure 1) exhibited the drought situations at the three gauging sites in 1926, 1983, 1997, 2005 and 2010, the worst being the droughts of 1997 and 2005. The 1926 drought was detected in the mean since it affected almost the whole hydrological year, while the droughts of 2005 or 2010 were noted as daily minimum values during the low water season (August-October).

The records at the Negro, Madeira and Amazon rivers (Figure 1) show a significant negative trend since the mid 1970s. In addition, according [3], a weak negative tendency in dry season precipitation is apparent in both southern and northern Amazonia starting in the mid 1970s, which seem to be related to interannual rainfall variability rather than to a gradual rainfall decline.

Figure 2 shows the floods in the three rivers as indicated by the maximum water levels. The maximum level was reached on 2012 for the Negro and Amazon rivers. Additionally, it can be observed that the 2005 drought presented a low maximum level for all three rivers.

Finally, a weak positive trend can be noticed in the levels at Manaus and Óbidos since the late 1980's. This suggests an exacerbation of the river's seasonal cycle during the last twenty years, with extreme high and low levels that broke any previous historic record. It is coherent with the hypothesis that extreme droughts and floods have become more frequent and intense [20], and this tendency could amplify in the future.

The impacts on vulnerable populations can also be analyzed from the Flow Duration Curve (FDC) (Figure 3). Thresholds for high/low levels were considered as average annual maximum/minimum level plus/minus one standard deviation, as suggested by the Geological Survey of Brazil-CPRM. In that sense, the impact of low/

Table 1. Location of gauge stations in Amazon basin.

\begin{tabular}{cccc}
\hline Station & River & Lat (S) & Lon (W) \\
\hline Manaus & Negro & -3.13 & -60.03 \\
Fazenda Vista Alegre & Madeira & -4.90 & -60.03 \\
Óbidos & Amazon & -1.95 & -55.51 \\
\hline
\end{tabular}




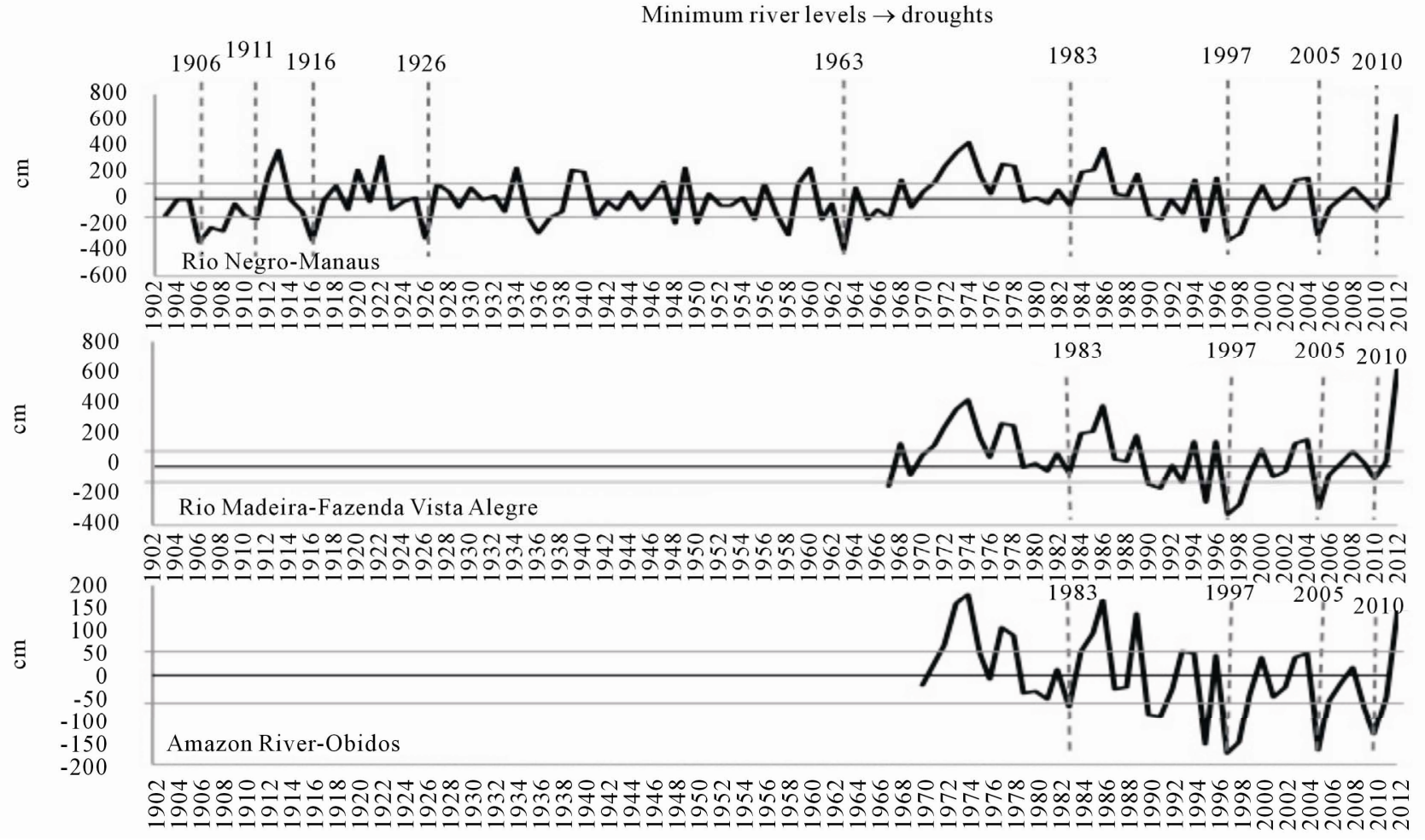

Figure 1. Annual minimum levels of the Rio Negro in Manaus for 1903-2012 (top panel); annual mean levels of the Madeira River at Fazenda Vista Alegre for 1967-2012 (middle panel), and discharges of the Amazonas River in Óbidos for 1970-2012 (bottom panel). Base period for calculations of the anomalies are from the mean of all data sets. Years with drought are indicated on the figures with broken lines. Gray lines represent $+/-$ one standard deviation.

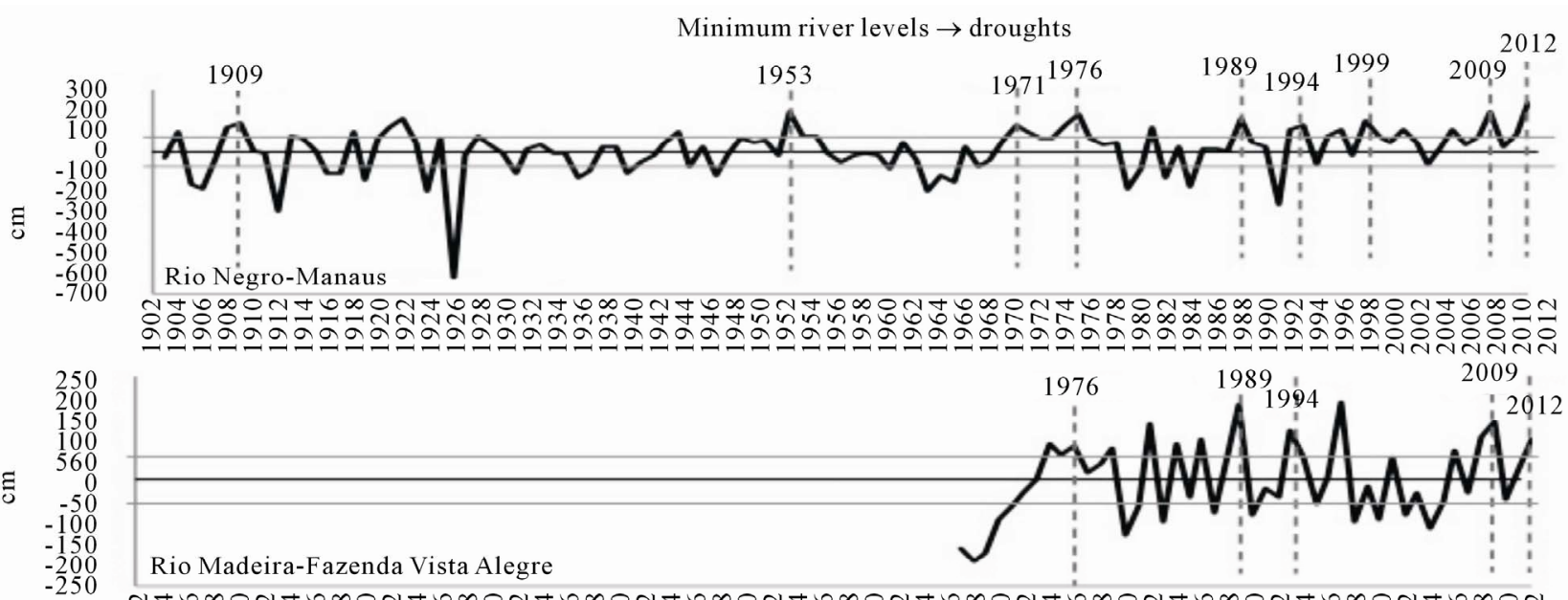

Rio Madeira-Fazenda Vista Alegre

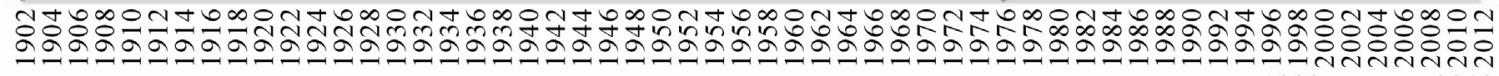

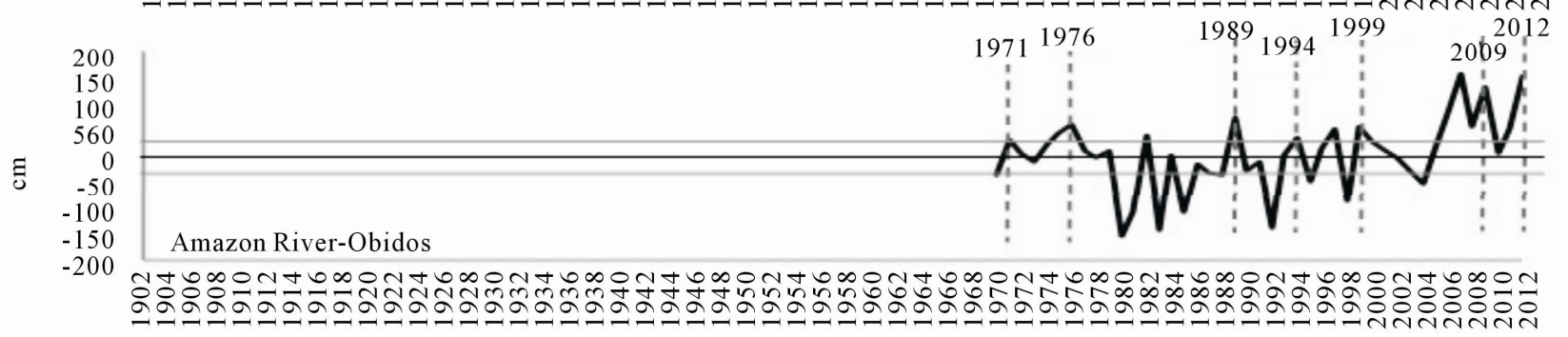

Figure 2. Same as in Figure 1 but for annual maximum levels/discharges. Years with floods are indicated with broken lines. 

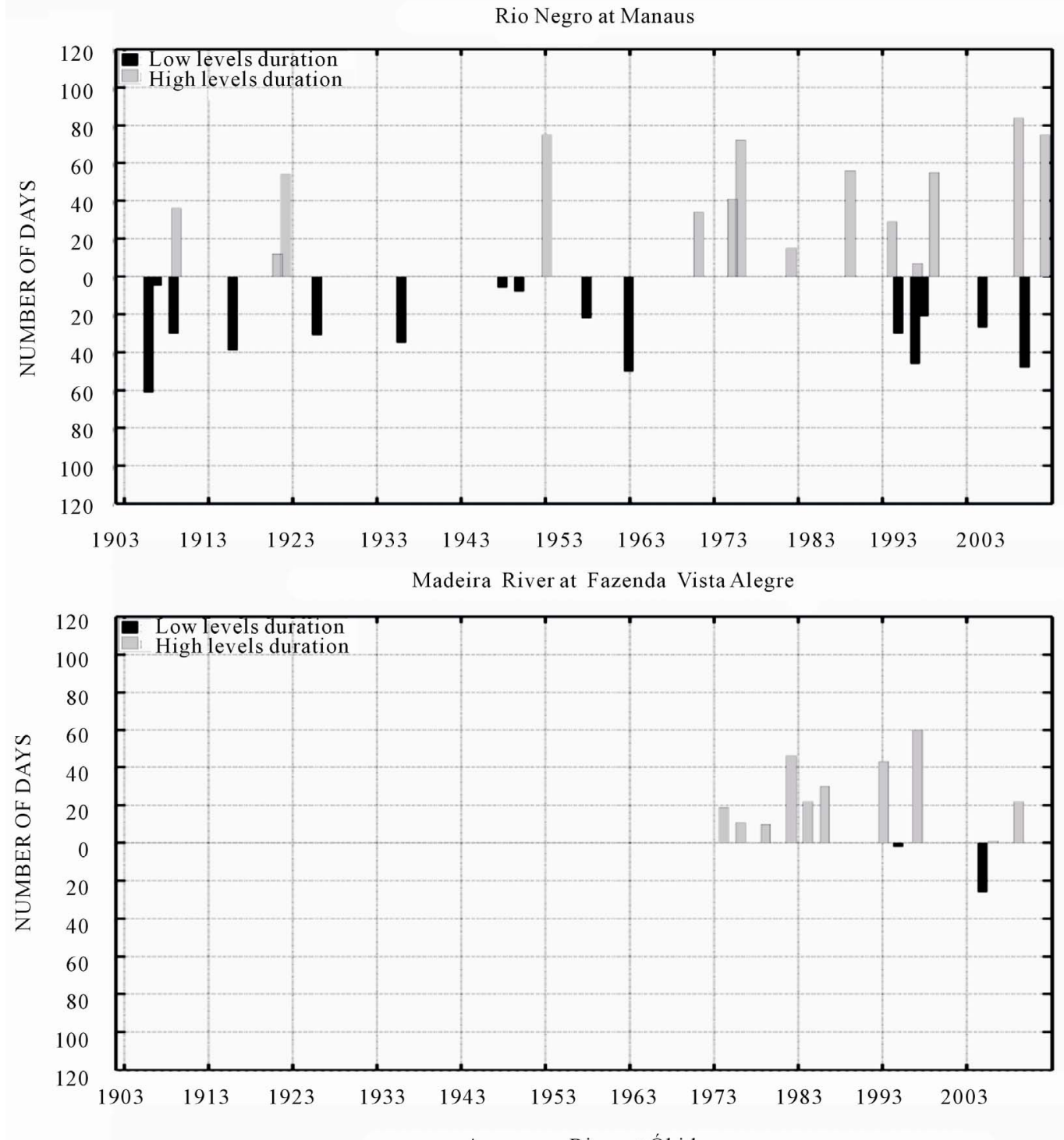

Amazonas River at Óbidos

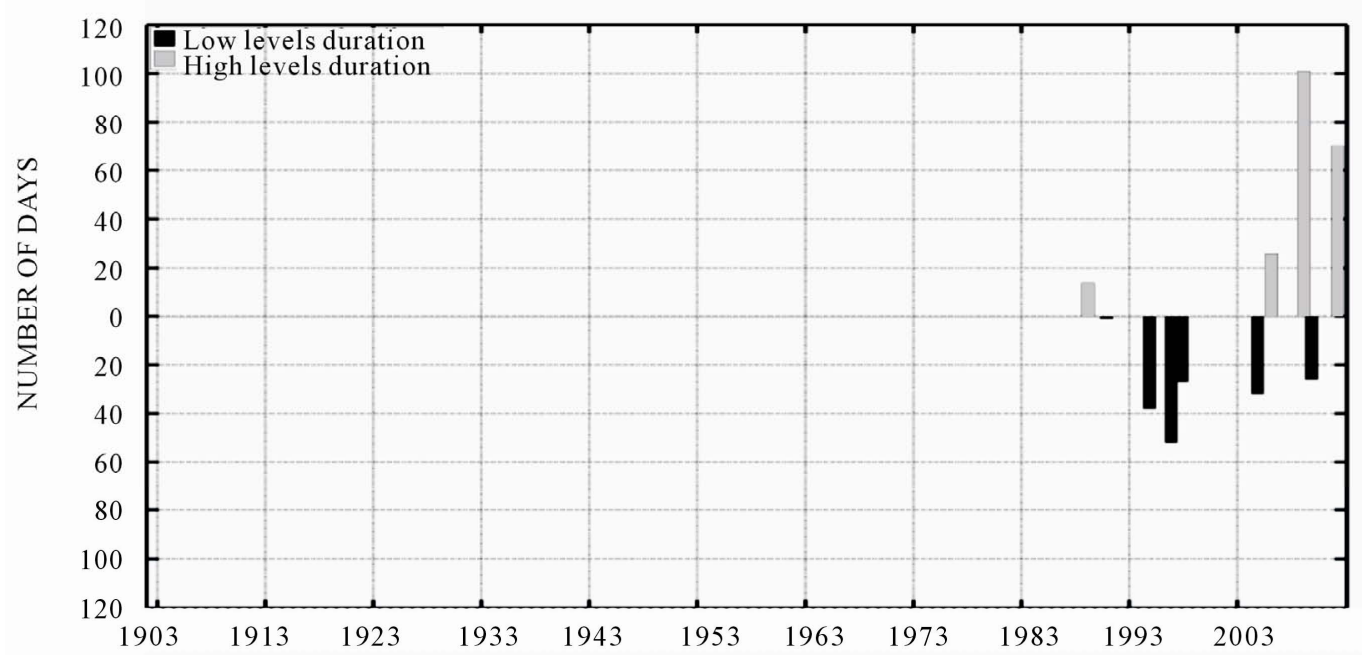

Figure 3. Duration of low levels (black) and high levels (shaded) in days, in Manaus, Vista Alegre and Óbidos gauge stations. Thresholds for high/low levels were definedas average annual maximum/minimum level plus/minus standard deviation. 
high river levels on natural and human systems also depends on how long these low/high levels are maintained. High levels of longer duration are able to increase direct flood damages, such as loss of human life, immediate health impacts, damage to buildings and economic goods, the altering of plant physiology and the functioning of ecological systems; and also indirect damages, such as disruption of the normal economic and social activities of the population.

It can be observed from Figure 3 that the longestlasting floods in the last 40 years in both the Manaus and Óbidos stations were in 2009 and 2012 while in Fazenda Vista Alegre, the floods of 1997, 1993 and 1982 had the longest durations registered. It is important to note that, at this last gauge station, there is no data level registers for the 2009 flood.

Also, longer-duration drought events can increase direct and indirect damages, such as impacts in navigation, food supply and fishing activities of local riverine communities, fresh water supply, fish mortality in floodplain lagoons, plant growth and greenness and fire risk [19]. Maintenance of this condition increases dissolved carbon and nutrient concentrations, turbidity and temperature, and diminishes dissolved oxygen percentages enhancing hyper eutrophic conditions in floodplain lakes [23]. The duration of low levels in 2010 was the longest in 40 years at the Manaus station, while in Óbidos the 1997 drought maintained lower levels longer than in 2010. On the other hand, in the Madeira River, at Fazenda Vista Alegre station, low levels dropped below threshold values only during the 1994 and 2005 droughts.

\section{Vulnerability of Local Populations and Natural Systems}

For this section we used, as much as possible, scientific published literature; also used were secondary data obtained from policy documents, reports from monitoring and emergency government agencies, local newspapers, and other literature about this particular drought and flood events.

As described in $[1,2,8,22,24]$, the 2005 drought in Amazonia was one of the worst on record there. Anecdotal evidence compiled in[8] indicates wide-ranging impacts of the drought on sectors such as fisheries, river and air transport, health and agriculture. As rivers dried up, remote communities were isolated and commerce slowed to a standstill. Health service data for the state of Acre in western Amazonia indicate that there was an increase in the number of hospital admissions and the cost of treatments for both respiratory illnesses and waterborne diseases during the months of drought (Jun-Dec 2005). Waterborne diseases could have been linked to low water quality as a result of reduced flow volumes.
Regarding air transportation, analysis of flight records in 2005 indicates that the number of domestic flights and the number of passengers flying declined during the months of the drought in the states of Rondonia and Amazonas [8].

Regarding impacts on agriculture and fisheries, [8] shows that Rondônia experienced the biggest loss in production, representing $7 \%$ and $19 \%$ of total production value for the years 2005 and 2006, respectively. Coffee appears to have been the most affected crop in Rondônia, with losses in production value of $75 \%$ and $82 \%$, in 2005 and 2006, respectively. The state of Acre exhibited a $15 \%$ loss in its total production value in 2006 . Its biggest losses were in manioc in 2006 , followed by coffee in the same year and beans in 2005 .

In addition, extractive fisheries showed losses in the three western Amazonian states: Rondônia, Acre and Amazonas. The reduction was particularly marked in Rondônia, dropping by almost half from previous levels. The states of Pará and Amazonas are the largest fish producers in the North. Pará produced 60,853 t, a decrease of $2.7 \%$ in 2005 compared to 2004. The species that contributed most to this decrease were: curimatã (74.2\%), tambaqui (35\%), and peacock piramutaba $(4.2 \%)$. The state of Amazonas, with a production of 55,413 tonnes, saw a drop in total catch size of $7.2 \%$ in 2005.

Although official fisheries statistical data available in the Amazon basin are highly limited, overfishing is widespread, with several species showing signs of severe decline and risk of extinction for instance, tambaqui and pirarucu $[5,25]$. This makes it difficult to distinguish the impact of overfishing and climatic variability on fisheries, but certainly, extreme droughts exacerbate threats to species. It is true that with increased interannual variability and incidence of extreme events in the region, climatic phenomena have been acting as another source of stress on food security, compromising the livelihood options for most of the Amazon inhabitants [6].

An interesting analysis performed by [5] and also described in [17] was on the perception of the drought of 2005 as compared to the previous drought in 1997. Stories about the 2005 drought were widely broadcast by the press; therefore, the governmental efforts (e.g., some state government set up a "situation room" in order to facilitate the flow of information and coordinate among government institutions) to cope with the drought impacts were more comprehensive, suggesting that the availability of new communication technology and greater public awareness regarding environmental issues, combined with the new legal framework for assessing the severity of calamities in Brazil, are among the primary factors that explain the difference in societal response between the two droughts. 
The same can be said for the drought of 2010, where several actions taken by the government through civil defense made use of past experiences such as from the 2005 drought [14]. Reports from government agencies indicate that population in rural areas has been using non-treated water, thus spreading waterborne diseases. Local authorities say around 62,000 families have been affected by the 2010 drought, and the Brazilian government released US \$13.5 million in emergency aid for Amazon regions hit by the 2010 drought, to fund water pumping and purification, as well as food deliveries to towns cut off by the drop in river levels. Most of the small commerce activities that depend on river transportation registered huge economic losses, with most of the small towns lacking basic food staples and medicine [28]. The same situation was observed in the Peruvian Amazon, where the authorities had to declare a state of public emergency due to problems in river transport and food supply to the population [26].

In the Brazilian state of Acre in western Amazonia, according to the local newspaper A Gazeta do Acre (I.F. Brown, personal communication), damages from previous extremes were heavy: 2009-US \$15 million; 2010 US \$21 million; 2011-US \$25 million, and 2012-US $\$ 100$ million.

In the area of ecological impacts, [27] shows that in an average year, the basin absorbs about 1.5 billion tonnes (metric tons) of $\mathrm{CO}_{2}$ from the atmosphere. By contrast, the impact of the 2005 drought, spread over a number of years, was calculated to have been a release of five billion tonnes. They calculate for 2010 the $\mathrm{CO}_{2}$ release as about eight billion tonnes, and the difference may be because the first drought may have weakened a large number of trees, thus increasing the number dying in the 2010 dry season. Two unusual and extreme droughts occurring within a decade may largely offset the carbon absorbed by intact Amazon forests during that time, and if these events become more frequent, this may affect the capacity of the forests to serve as sink of carbon.

In 2009 the flooding was extreme and has severely negatively impacted most of the riverine communities in the Brazilian Amazon basin. National and local newspapers have broadcast it as the second worst flood of the century with 21 municipalities impacted (34\%). The government of Amazonas state released US \$150 million to help with reconstruction of houses of the impacted families but has evidenced how unprepared the civil defense was to attend to affected population by floods in the Amazon where no emergency plan existed until then.

In 2012, a swath of the Brazilian Amazon was under a state of emergency as rivers overflowed in one of the worst floods on record according to data from different government monitoring agencies and local newspapers. The rise of the levels of the Rio Negro and the Solimões flooded various highways in the state of Amazonas, affecting traffic due to damages to roads and bridges. The Civil Defense of this state reported in May 2012 that there were floods in 16 neighborhoods of the city of Manaus, and the rising waters affected touristic attracttions, local small business, the city's downtown and the local port facilities, affecting more than 29,000 people. This situation was worse than in the previous flood in 2009.

In the Brazilian Amazon, chronic underinvestment in small-scale agriculture and rural development serving the country's poorest population compound the challenges of mitigating the negative impact of climatic anomalies upon both socio-ecological systems. In sum, the poorest members of society in the Amazon region have been the most negatively affected by the drought or floods, but there are also some significant impacts on health, commerce, agriculture and other human activities in both rural and urban areas, that raise the total cost of such hazards.

It is a fact that in all recent major droughts and floods the impacts on local vulnerable population are still considerable. This is an indicator of how governmental agencies are still unprepared to efficiently implement adaptation strategies to cope with such extremes.

\section{Experiences of Adaptation in Amazonia Incoping with Drought and Flood Hazards: Suitable Adaptation Strategies}

There is a lack of consensus in acceptance of the fact that the frequent natural disasters such as floods and droughts occurring now are products of climate change. The severe droughts in 2005 and 2010 did fit future projections of some climate models, in the sense that the forest may face greater weather extremes this century, with more intense droughts, making it more vulnerable to fires, which in turn could damage its ability to recover. However, the occurrence of wet episodes in 2009 and 2012 between these droughts challenges this argument. What may be concluded is that extremes in climate vari- ability may become more frequent in the future, as shown by [20].

It has been noticed that although developing countries have been acting strongly on climate change mitigation strategies, they are still behind on climate change adaptation. Among several reasons (outside the scope of this work), there are still barriers to adaptation found in Amazonia and in any country in Latin America. They include lack of 1) awareness, 2) understanding and, 3) capacity to make decisions (both scientific and management). The processes needed to overcome these barriers take years to develop. However, with dedicated effort, countries can evolve a greater understanding of the dif- 
ficulties. The premise is that people need to see the possibility and benefits of specific action, identifying locally achievable methods for improving resilience to hazards stemming from of extremes of climate variability and even climate change.

Bad adaptive responses can be confronted with good and robust adaptive responses that can be widely appreciated as improving cultural, economic and ecological resilience to observed climate extremes, whether or not climate change occurs. Reference [28] studied the extent of vulnerability of small and large farms to these events in a tropical rainforest environment, and reported on farmers' coping strategies in the Brazilian Amazon, in response to El Niño related droughts. In the Amazon, vulnerability is related to the reliance of the farming population upon adequate rainfall, and onset and end of the rainfall cycle, for the attainment of good harvests given the local agricultural cycle. Most of the traditional inhabitants in the Amazon are closely dependent on extraction of natural resources that are directly associated with the annual hydrological cycle and thus highly vulnerable to climatic and hydrological anomalies [18].

Furthermore, in [29] it was concluded that although a range of locally developed forecasting techniques and coping mechanisms was found, farmers have sustained significant losses, and it was suggested that increased access to scientific forecasts could enhance the ability of the farmers in the study area to cope with drought. This fits with the need for long-term climate and hydrological monitoring and forecasting, as a tool to provide information for potential users, with the intention of being ready to cope with the possible impacts of droughts or floods, and to increase their resilience in the face of extreme hazards. The study also highlighted the challenges of adaptation to climate change created by the influence of migration and family turnover and loss of knowledge of past extreme events, as well as the mismatch of scales used to monitor and disseminate climate data and the lack of extension services to translate large-scale forecasts to local needs.

Figure 4 shows some ways of adaptation that are or could be applied in Amazonia. Options (a) and (c) include short- and long-term planning, including risk analyses and vulnerability assessments so as to identify where people exposed to hazards live as well as emergency action and contingency plans to move populations to temporary shelters suitable for use during the time in which the hazard is still present.

Assessing the risk situation by means of climatic-hydrological monitoring, the issuing of accurate regional climate forecasts, and the actions of national emergency plans driven by the local and regional civil defense, together with the creation of centers that process climate and hydrological information warning of droughts or

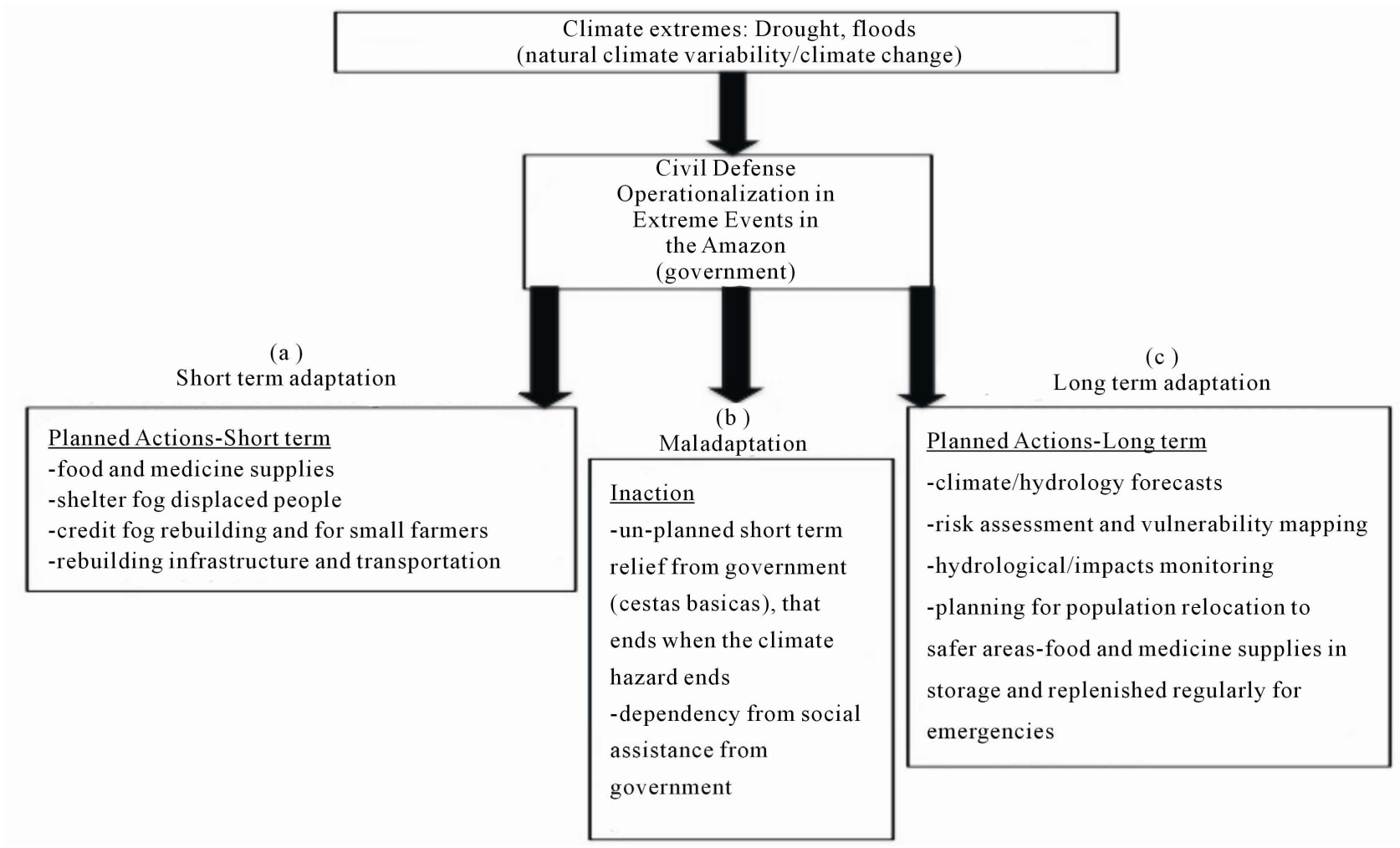

Figure 4. Conceptual model: factors affecting adaptive responses to climate variability and change in a multilevel perspective in Amazonia. 
floods and issuing of alerts are examples of long term adaptation measures (c).

In 2010, five years after the drought of 2005, many people were affected by the low river water levels, and smoke from fires, as in 2005, and again the government sent food supply kits (cestas básicas in Portuguese), medical supplies and drinking water to people isolated in small towns using helicopters from the Brazilian Air Force [14], spending the equivalent of millions of dollars on this strategy. Once the drought situation ended in 2011, this help from the government stopped.

During the flood of 2012, three years after the floods of 2009, the city of Manaus again experienced the impacts of high water levels of the Rio Negro, and street and local businesses were again flooded. As in 2009, emergency was declared in many districts of the state of Amazonas in Brazil and in the lower Amazonia sectors of Peru and Colombia, so that governments could providecestas básicas and medical supplies for waterborne diseases for people in rural areas and that had been hit again.

As in the drought situations, help from the government ended once the flood hazard ended. This is shown as option (b) in Figure 4, and in fact represents an immediate response action that ends once the hazard is over. Thiscould be an example of expensive short-term emergency aid, that could be thought as one form of "maladaptation", that somewhat solves the immediate problem, but that inthe long term makes things worse, since people do not adapt to climate hazards and keep depending on government assistance.

\section{Final Thoughts}

Droughts and floods are part of the natural climate variability in these regions and have occurred in the past and will continue in the future. The last ten years have featured the most intense droughts and floods in recent history, and the prospects of this situation continuing in the future are still high, even given the uncertainties. River levels are perhaps the best way to assess climatic hazards in the basin, particularly droughts and floods. Vulnerable people living on the banks of the main Amazonian rivers are among the most affected by these extreme events; but the natural ecosystems in the region are affected as well.

The current drought and flood policies in the Amazon region may be an example of maladaptation, since they may undermine resilience, and seem to be ineffective in reducing vulnerability for the majority of the population. While efforts have been devoted to mitigation by reduceing deforestation in the region, it is clear that the Amazon requires new approaches to understanding and practicing adaptation. It is important to remember that the perception of impacts of extremes of the climate variability and change may be different at the state-regional versus the national-federal scales.

There is an important role for climate and hydrology monitoring and forecasting as well as the dissemination of these products that reach various levels of users, from small farmers and vulnerable people to policymakers. Using forecast products, decision makers can think about possible adaptation strategies to cope with such climatic hazards.

Well-suited government policies in Amazonia for adaptation and vulnerability assessments must be taken into account to help populations cope with the extremes of climate variability, and to the prospects of more intense extremes in future climate change scenarios. Research should aim to assess directly how droughts and floods affect the health and livelihoods of people living in the region and for those who depend most closely on Amazonian ecosystems, and who have the fewest resources at their disposal to cope with adverse conditions.

\section{Acknowledgements}

The research leading to these results has received funding from the European Community's Seventh Framework Programme Project No. 282664: AMAZALERT. Additional funding wasprovided by the projects RedeCLIMA, the National Institute of Science and Technology for Climate Change (INCT-CC), from the FAPESPAssessment of Impacts and Vulnerability to Climate Change in Brazil and strategies for Adaptation options project (Ref. 2008/58161-1) and from FAPESP-RCUKImpacts of Climate Extremes on Ecosystems and Human Health in Brazil:PULSE-BRAZIL (Ref. 2011/51843).

\section{REFERENCES}

[1] J. A. Marengo, C. A. Nobre, J. Tomasella, M. Oyama, G. Sampaio, H. Camargo and L. Alves, "The Drought of Amazonia in 2005," Journal of Climate, Vol. 21, No. 3, 2008, pp. 495-516. doi:10.1175/2007JCLI1600.1

[2] J. A. Marengo, J. Tomasella, L. Alves, W. Soares and D. A. Rodriguez, "The Drought of 2010 in the Context of Historical Droughts in the Amazon Region," Geophysical Research Letters, Vol. 38, No. 12, 2011, pp. 1-5. doi:10.1029/2011GL047436

[3] J. A. Marengo, , J. Tomasella, W. Soares, L. Alves and C. A. Nobre, "Extreme Climatic Events in the Amazon Basin: Climatological and Hydrological Context of Previous Floods," Theoretical and Applied Climatology, Vol. 85, 2011, pp. 1-13.

[4] J. A. Marengo, L. Alves., W. Soares, D. A.Rodriguez, H. Camargo, M. ParedesRiveros and A. Diaz Pabló, "Two Contrasting Severe Seasonal Extremes in Tropical South America in 2012: Flood in Amazonia and Drought in Northeast Brazil," 2013 (in press).

[5] P. F. Pinho, "Dynamics and Consequences of Natural 
Resources Management: Perspectives from a Local Caboclo Fishery in Silves, Central Brazilian Amazon," Ph.D. Thesis. University of California, Davis, 2007.

[6] O. L. Philipps, et al. "Drought Sensitivity of the Amazon Rainforest," Science, Vol. 323, No. 5919, 2009, pp. 1344-1347. doi:10.1126/science.1164033

[7] L. E. O. Aragão, Y. Malhi, R. M. Roman-Cuesta, S. Saatchi, L. O. Anderson and Y. Shimabukuro, "Spatial Patterns and Fire Response of Recent Amazonian Droughts," Geophysical Research Letters, Vol. 34, No. 7, 2007, Article ID: L07701. doi:10.1029/2006GL028946

[8] L. O. Anderson, M. Trivedi, J. Queiroz. L. Aragão. J. A. Marengo, C. Young and P. Meir, "Counting the Costs of the 2005 Amazon Drought: A Preliminary Assessment," In: P. Meir, A. Mitchell, J. Marengo, C. Young, G. Poveda, C. A. Llerena, L. Rival, L. Meneses, A. Hall, R. Betts, J. Farley, S. Fordham and M. Trivedi, Eds., Ecosystem Services for Poverty Alleviation in Amazonia, Global Canopy Programme and University of Edinburgh, Edinburgh, 2011 pp. 96-108.

[9] J. Ronchail, G. Cochonneau, M. Molinier, J. L. Guyot, A. G. M. Chaves, V. Guimarães and E. Oliveira, "Interannual Rainfall Variability in the Amazon Basin and Sea-Surface Temperatures in the Equatorial Pacific and the Tropical Atlantic Oceans," International Journal of Climatology, Vol. 22, No. 13, 2002, pp. 1663-1686. doi: $10.1002 /$ joc. 815

[10] N. Zeng, et al., "Causes and Impact of the 2005 Amazon Drought," Environmental Research Letters, Vol. 3, No. 1, 2008, Article ID: 014002. doi:10.1088/1748-9326/3/1/014002

[11] J. H. Yoon and N. Zeng, "An Atlantic Influence on Amazon Rainfall," Climate Dynamics, Vol. 34, No. 2-3, 2010, pp. 249-264. doi:10.1007/s00382-009-0551-6

[12] P. Satyamurty, A. A. de Castro, J. Tota, L. E. da Silva Gularte and A. O. Manzi, "Rainfall Trends in the Brazilian Amazon Basin in the Past Eight Decades," Theoretical and Applied Climatology, Vol. 99, No. 1-2, 2010, pp. 139-148. doi:10.1007/s00704-009-0133-x

[13] J. A. Marengo, "Long Term Trends and Cycles in the Hydrometeorology of the Amazon Basin since the Late 1920's," Hydrological Processes, Vol. 23, No. 22, 2009 , pp. 3236-3244. doi:10.1002/hyp.7396

[14] L. S. Borma, J. Tomasella, S. T. Roballo, L. A. Cuartas, D. A. Rodriguez, J. A. Marengo and C. A. Nobre, "Impactos Dos Eventos Extremos de Seca e Cheia Sobre os Recursos Hídricos Amazônicos, Desastres Naturais e Ações da Defesa Civil," In: L. S. Borma and C. A. Nobre, Eds., Secas na Amazônia, Oficina de Textos, São Paulo, 2013 (in Portuguese).

[15] B. Meggers, "Archeological Evidence for the Impact of Mega-Niño Events on Amazônia during the Past Two Millennia," Climate Change, Vol. 28, No. 4, 1994, pp. 321-338. doi:10.1007/BF01104077

[16] E. Williams, A. Dall'Antonia, V. Dall'Antonia, J. de Almeida, F. Suarez, B. Liebmann and A. Malhado, "The Drought of the Century in the Amazon Basin: An Analysis of the Regional Variation of Rainfall in South America in 1926," Acta Amazonica, Vol. 35, No. 2, 2005, pp.

\section{1-238. doi:10.1590/S0044-59672005000200013}

[17] J. Tomasella, P. F. Pinho, L. S. Borma, J. A. Marengo, C. A. Nobre, O. R., Bittencourt, M. C. R. Prado, D. A. R. Rodriguez and L. A. Cuartas, "The Droughts of 1997 and 2005 in Amazonia: Floodplain Hydrology and Its Potential Ecological and Human Impacts," Climatic Change, Vol. 116, No. 3-4, 2013, pp. 723-746. doi:10.1007/s10584-012-0508-3

[18] P. F. Pinho, J. A. Marengo and M. Sttaford Smith, "Complex Socio-Ecological Dynamics behind Extreme Events in the Amazon," 2012 (unpublished).

[19] L. Xu, A. Samanta, M. Costa, S. Ganguly, R. Nemani and R. Myneni, "Widespread Decline in Greenness of Amazonian Vegetation Due to the 2010 Drought," Geophysical Research Letters, Vol. 38, 2011, Article ID: L07402.

[20] S. I. Seneviratne, N. Nicholls, D. Easterling, C. M. Goodess, S. Kanae, J. Kossin, Y. Luo, J. Marengo, K. McInnes, M. Rahimi, M. Reichstein, A. Sorteberg, C. Vera and X. Zhang, "Changes in Climate Extremes and Their Impacts on the Natural Physical Environment," In: C. B. Field, V. Barros, T. F. Stocker, D. Qin, D. J. Dokken, K. L. Ebi, M. D. Mastrandrea, K. J. Mach, G.-K. Plattner, S. K. Allen, M. Tignor and P. M. Midgley, Eds., Managing the Risks of Extreme Events and Disasters to Advance Climate Change Adaptation, A Special Report of Working Groups I and II of the Intergovernmental Panel on Climate Change (IPCC), Cambridge University Press, Cambridge, New York, 2012, pp. 109-230.

[21] J. C. Espinoza J. Ronchail, J. L. Guyot, C. Junquas, G. Drapeau, J. M. Martinez, W. Santini, P. Vauchel, W. Lavado, J. Ordoñez and R. Espinoza, "From Drought to Flooding: Understanding the Abrupt 2010-2011 Hydrological Annual Cycle in the Amazonas River and Tributaries," Environmental Research Letters, Vol. 7, No. 2, 2012, Article ID: 024008. doi:10.1088/1748-9326/7/2/024008

[22] J. Tomasella, L. S. Borma, J. A. Marengo, D. A. Rodri guez, L. A. Cuartas, C. A. Nobre and M. C. R. Prado, "The Droughts of 1996, 1997 and 2004, 2005 in Amazonia: Hydrological Response in the River Main-Stem," Hydrological Processes, Vol. 25, No. 8, 2010, pp. 12281242. doi:10.1002/hyp.7889

[23] A. G. Affonso, H. L. Queiroz and E. M. L. Novo, "Limnological Characterization of Floodplain Lakes in Mamirauá Sustainable Development Reserve, Central Amazon (Amazonas State, Brazil)," Acta Limnologica Brasiliensia, Vol. 23, No. 1, 2011, pp. 95-108.

[24] C. A. S. Coelho, I. Cavalcanti, S. M. S. Costa, S. R. Freitas, E. R. Ito, G. Luz, A. F. Santos, C. A. Nobre, J. A. Marengo and A. B. Pezza, "Climate Diagnostics of Three Major Drought Events in the Amazon and Illustrations of Their Seasonal Precipitation Predictions," Meteorological Applications, Vol. 19, No. 2, 2012, pp. 237-255. doi: $10.1002 /$ met. 1324

[25] L. Castello, J. P. Viana, G. Watkins, M.Peno-Vasquez and V. A. Luzadis, "Lessons from Integrating Fishers of Arapaima in Small-Scale Fisheries Management at the Mamirauá Reserve, Amazon," Environmental Management, Vol. 12, 2008, pp. 197-209.

[26] E. F. Moran, R. Adams, B. Bakoyéma, S. Fiorini and B. 
Boucek, "Human Strategies for Coping with El Niño Related Drought in Amazônia," Climate Change, Vol. 77, No. 3-4, 2006, pp. 343-361. doi:10.1007/s10584-005-9035-9

[27] J. C. Espinoza, J. Ronchail, J. L. Guyot, C. Junquas, P. Vauchel, W. Lavado, G. Drapeau and R. Pombosa, "Climate Variability and Extreme Drought in the Upper Solimões River (Western Amazon Basin): Understanding the Exceptional 2010 Drought," Geophysical Research Letters, Vol. 38, No. 13, 2011, Article ID: L13406. doi:10.1029/2011GL047862
[28] S. L. Lewis, P. M. Brando, O. L. Phillips, M. F. van der Heijden and D. Nepstad, "The 2010 Amazon Drought," Science, Vol. 331, No. 6017, 2011, p. 554. doi:10.1126/science. 1200807

[29] E. S. Brondizio and E. F. Moran, "Human Dimensions of Climate Change: The Vulnerability of Small Farmers in the Amazon," Philosophical Transactions of the Royal Society B, Vol. 363, No. 1498, 2008, pp. 1803-1809. doi:10.1098/rstb.2007.0025 